\title{
A higher proportion of squamous intraepithelial lesion of the cervix in symptomatic HIV-infected women at a tertiary health center in Tanzania
}

Joseph Obure ${ }^{1,2^{*}}$, Pendo Mlay ${ }^{1}$, Gileard Masenga', Olola Oneko ${ }^{1}$, David Walmer ${ }^{2}$

From $12^{\text {th }}$ International Conference on Malignancies in AIDS and Other Acquired Immunodeficiencies (ICMAOI)

Bethesda, MD, USA. 26-27 April, 2010

\section{Background}

Many study reports have associated cervical squamous intraepithelial lesion (SIL) and HIV infection [1,2]. In Tanzania, however, there are limited and conflicting published reports on the association between HIV infection and SIL [3]. A study was conducted to determine the proportion and severity of SIL in HIV-infected women attending a cervical cancer screening clinic at Kilimanjaro Christian Medical Center (KCMC) in
Tanzania. A total of 214 women 18 to 60 years old, among whom 99 (46.3\%) and 115 (53.7\%) were HIV-seropositive and HIV-seronegative, respectively, were recruited in the study. Blood samples were taken to associate SIL and degree of HIV infection by CD4+ T lymphocyte counts. Structured questionnaires with socio-demographic characteristics were administered while cervical smears were taken from all women to determine and grade the degree of SIL. High-grade and

Table 1 Relationship between HIV serostatus and cervical SIL (n, 214)

\begin{tabular}{|c|c|c|c|c|c|c|}
\hline Variable & Total & Pap results & & Chi-square & p-value & OR $(95 \% \mathrm{Cl})$ \\
\hline & & SIL & Normal & & & \\
\hline & & No (\%) & No (\%) & & & \\
\hline HIV-seropositive & 99 & $32(32.3)$ & $67(67.7)$ & & & \\
\hline HIV-seronegative & 115 & $4(3.5)$ & $111(96.5)$ & 31.5 & $<0.001$ & $13.3(4.2-46.4)$ \\
\hline
\end{tabular}

Note; Pap = Papanicolous smear; SIL = Squamous Intraepithelial Lesion.

Table 2 Relationship between SIL and HIV disease progression according to CD4+ T lymphocyte count (cells/microL)

\begin{tabular}{llllll}
\hline Variable & Total & PAP smear results & Chi-square & p-value \\
\hline & & SIL & Normal & & \\
CD4+ T lymphocyte cell Count (cells/microliter): & & & & & \\
\hline Less than 200 & 31 & $18(58.1)$ & $13(41.9)$ & & \\
\hline $200-499$ & 49 & $32(32.3)$ & $38(77.6)$ & & \\
\hline 500 or more & 19 & $4(3.5)$ & $16(96.5)$ & 13.9 & 0.001
\end{tabular}

Note: PAP = Papanicolous; SIL = Squamous Intraepithelial Neoplasia.

\footnotetext{
*Correspondence: jobure2002us@yahoo.com

${ }^{1}$ Department of Obstetrics and Gynecology, Kilimanjaro Christian Medical

CenterMoshi, Kilimanjaro, Tanzania

Full list of author information is available at the end of the article
} 
Table 3 Relationship between degree of SIL and degree of HIV progression ( $n=99)$

\begin{tabular}{|c|c|c|c|c|c|c|}
\hline \multirow[t]{2}{*}{ Variable } & \multirow[t]{3}{*}{ Total } & \multicolumn{3}{|c|}{ PAP smear results } & \multirow[t]{2}{*}{ Chi-square } & \multirow[t]{2}{*}{$\mathrm{p}$-value } \\
\hline & & HGL & LGL & Normal & & \\
\hline & & No. (\%) & No. (\%) & No. (\%) & & \\
\hline \multicolumn{7}{|c|}{ CD4+ T lymphocyte cell Count (cells/microliter): } \\
\hline Less than 200 & 31 & $7(22.6)$ & $11(35.5)$ & $13(14.9)$ & & \\
\hline $200-499$ & 49 & $4(8.2)$ & $7(14.3)$ & $38(77.6)$ & & \\
\hline 500 or more & 19 & $1(5.3)$ & $2(10.5)$ & $16(84.2)$ & 14.0 & 0.007 \\
\hline
\end{tabular}

Note: PAP = Papanicolous; HGL = High-Grade Squamous Intraepithelial Lesion; $L G L=$ Low-Grade Squamous Intraepithelial Lesion.

low-grade squamous intraepithelial lesions were regarded as abnormal smear. Overall proportion of SIL was $17 \%$. Proportion of SIL among HIV-seropositive subjects was $32 \%$ versus $4 \%$ in seronegative subjects $(\mathrm{OR}=13.3$, 95\% CI=4.2-46.4) (see Table 1). Low CD4+ T lymphocyte cell count was associated with higher proportion of SIL $(p=0.001)$ (see Table 2). The relationship between CD4+ T lymphocyte cell counts and the severity of cervical SIL was significant $(\mathrm{p}=0.007)$ (see Table 3). Marital status and number of lifetime sex partners were risk factors significantly associated with SIL $(\mathrm{p}=0.004$ and 0.005 , respectively). There was no association between SIL with age, education level, parity, or age at sex debut.

\section{Conclusion}

SIL diagnosis was significantly associated with HIV infection with inverse relationship between HIV disease progression and degree of SIL. These findings underscore the need for HIV screening among women with SIL, and the need for cervical cancer screening in HIV-infected women. Marital status and number of lifetime sex partners were significant risk factors associated with SIL.

\section{Acknowledgements}

This article has been published as part of Infectious Agents and Cancer Volume 5 Supplement 1, 2010: Proceedings of the $12^{\text {th }}$ International Conference on Malignancies in AIDS and Other Acquired Immunodeficiencies (ICMAOI). The full contents of the supplement are available online at http://www.biomedcentral.com/1750-9378/5?issue=S1.

\section{Author details}

${ }^{1}$ Department of Obstetrics and Gynecology, Kilimanjaro Christian Medical CenterMoshi, Kilimanjaro, Tanzania. ${ }^{2}$ Departments of Obstetrics and Gynecology, Duke University Medical Center, Durham, NC, USA.

Published: 11 October 2010

doi:10.1186/1750-9378-5-S1-A1

Cite this article as: Obure et al: A higher proportion of squamous intraepithelial lesion of the cervix in symptomatic HIV-infected women at a tertiary health center in Tanzania. Infectious Agents and Cancer 2010 5(Suppl 1):A1.
Submit your next manuscript to BioMed Central and take full advantage of:

- Convenient online submission

- Thorough peer review

- No space constraints or color figure charges

- Immediate publication on acceptance

- Inclusion in PubMed, CAS, Scopus and Google Scholar

- Research which is freely available for redistribution

Submit your manuscript at www.biomedcentral.com/submit 